\title{
ULTRAHANGOS ANYAGVIZSGÁLAT ELJÁRÁSVÁLTOZATAINAK ALKALMAZHATÓSÁGA
}

\section{APPLICABILITY OF PROCEDURAL VARIANTS IN ULTRASONIC TESTING}

\author{
Bagyinszki Gyula, ${ }^{1}$ Bitay Enikő ${ }^{2}$ \\ ${ }^{1}$ Óbudai Egyetem, Bánki Donát Gépész és Biztonságtechnikai Mérnöki Kar, Budapest, Magyarország, \\ bagyinszki.gyula@bgk.uni-obuda.hu \\ ${ }^{2}$ Sapientia Erdélyi Magyar Tudományegyetem, Marosvásárhelyi Kar, Marosvásárhely, Románia, \\ ebitay@ms.sapientia.ro
}

\begin{abstract}
Ultrasonic testing (UT) is essentially the transmission of high-frequency $(0.25 \ldots 20 \mathrm{MHz}$ ) sound waves (mechanical vibration and energy) into a material, in order to interact with the macro-structural constituents of the material which reflect and/or weaken it. Ultrasonic testing - as one of the most common nondestructive material testing (NDT) methods - thanks to its many variants, is able to operate in a mobilized and highly automated fashion; it can be performed on most material types; high accuracy and reproducibility can be achieved in error detection, and it is generally enough if only one side is accessible; changes in elevation can also be verified with this method besides distance measurement, and it is also suitable for determining certain material characteristics. The present article reviews the application technology characteristic of the procedural variants.
\end{abstract}

Keywords: mechanical vibration, coupling, transmitter, receiver, discontinuity, fault signal

\section{Összefoglalás}

Az ultrahangos anyagvizsgálat (Ultrasonic Testing, UT) lényegében nagyfrekvenciájú (0,25...20 MHz) hanghullámok (mechanikai rezgés, ill. energia) átvitele az anyagba, hogy az kölcsönhatásba lépjen az anyag belső makroszerkezeti összetevőivel, amelyek azt visszaverik és/vagy gyengítik. Az ultrahangos vizsgálat - mint az egyik leggyakoribb roncsolásmentes anyagvizsgálat (Non-Destructive Testing, NDT) - eljárásváltozatai révén képes mobilizált, ill. nagymértékben automatizált működésre; minden anyagfajtán végrehajtható; nagy pontosság és reprodukálhatóság érhető el a hibák észlelésében; általában csak egy oldalnak kell hozzáférhetőnek lennie; a távolságmérés mellett szintváltozás is ellenőrizhető általa; anyagok egyes tulajdonságainak meghatározására is alkalmas. Jelen cikk az eljárásváltozatok alkalmazástechnikai jellemzőit tekinti át.

Kulcsszavak: mechanikai rezgés, csatolás, adó, vevő, folytonossági hiány, hibajel

\section{Bevezetés}

Az elektromos hálózati 50 Hz-es elektromágneses rezgés (váltakozó feszültség, ill. áram) által bevitt energia nagyfrekvenciájú mechanikai rezgéssé (ultrahanggá), ill. energiává történő átalakítását egy rezonátor végzi, mely

-a pozitív vagy negatív longitudinális magnetostrikció mint a ferromágneses testek mág- nesezettsége és mechanikai feszültségi állapota közti kapcsolat egyik megnyilvánulása;

- vagy az elektrostrikció mint reciprok piezoelektromos hatás

jelenségén alapul [1].

A magnetostrikció alkalmazásakor az elektromos hálózati kisfrekvencia nagyfrekvenciássá alakításával és annak tekercsbe táplálásával létrehozott váltakozó axiális mágneses térerő me- 
chanikai rezgésként (kis amplitúdójú hosszirányú rugalmas alakváltozásként) nyilvánul meg a mágneses mezőben célszerüen elhelyezett ferromágneses anyagban. Tehát a váltakozó árammal táplált tekercs ferromágneses anyagú (vas)magja erőteljes hosszrezgéseket végez, azaz ultrahanghullámokat bocsát ki, ha annak sajátfrekvenciája megegyezik a váltakozó áram frekvenciájával.

Az elektrostrikció az aktív dielektrikumok sajátossága, ami váltakozó elektromos tér (feszültség) hatására jelentkező váltakozó rugalmas deformáció, vagyis mechanikai rezgés, kellően nagy frekvencia esetében ultrahang. Ezen mechanikai rezgés amplitúdója rezonancia folytán akkor a legnagyobb, ha az elektromos tér rezgéseinek frekvenciája megegyezik a dielektrikumkristály valamelyik sajátfrekvenciájával. Ennek inverz jelensége a piezoelektromosság, amikor rugalmas deformáció (pl. visszaverődött ultrahang) hatására ellentétes előjelű polarizációs töltések (elektromos feszültség) jelennek meg az aktív dielektrikum megfelelően kialakított kristálydarabjai felületén, ami felerősített jelként kiértékelhető.

Az ultrahangos anyagvizsgálat során pl. egy kvarckristály elektrostrikció révén periodikusan változtatja méretét, és a környező közegben nyomáshullámokat (ultrahangot) gerjeszt (,adó” üzemmód). A jelenség inverzeként, ha a kristályt mechanikai hatás (pl. visszaverődött ultrahang) éri, akkor a rezgés frekvenciájának megfelelő elektromos feszültség (mint értékelhető jel) keletkezik benne (,vevő” üzemmód).

A hangtérben a mechanikai hullámok különféle formában terjednek: longitudinális (nyomáshullám), transzverzális (nyíráshullám) és Rayleigh(felületi) hullám. A longitudinális hullámnál a részecskemozgás és a terjedési irány azonos, transzverzális hullámnál ezek merőlegesek egymásra.
A Rayleigh-hullámnál a transzverzális hullámra jellemző részecskemozgás csak a felületi rétegekre jellemző, a felület alatt a hullámzás egyre gyengül.

Ha folytonossági hiányok találhatók a hangútban, akkor a mechanikai energia egy része visszaverődik a folytonossági hiányok mint reflektorok felületéről. A visszavert hanghullámjelet ezután visszaalakítják elektromos jellé, és intenzitását alkalmas kijelzőn jelenítik meg. A hanghullámok áthatolási ideje közvetlenül összekapcsolható a jel által megtett távolsággal. A jel alapján meg lehet határozni a reflektor helyére, méretére, orientációjára és más jellemzőire vonatkozó információkat. Az alkalmazás céljától függően többféle ultrahangvizsgálati eljárásváltozatot különböztetnek meg.

\section{Hangoptikai (Sound-Optical, SO) eljá- rás}

Elve a röntgenvizsgálatéhoz (1a. ábra) hasonló, ugyanis a vizsgált objektumban lévő hibáról az ultrahang visszaverődik, de a hibátlan helyeken túljutó hullámokat felfogják, optikai fényjellé alakítják át, és ez alapján állapítják meg a folytonossági hiány jelenlétét. Az eljárás vázlatát az 1b. ábra mutatja [2].

\section{3. Átsugárzásos (Through Transmission, TT) eljárás}

Az eljárás külön jeladókat használ az ultrahang kibocsátására és fogadására. Az adószondát a tesztminta egyik oldalán, a vevőátalakítót a másik oldalon kell elhelyezni. Ahogy a hang áthalad a vizsgálati darabon, és a terjedés útjába folytonossági hiány kerül, akkor ott az ultrahangsugárzás egy része nem jut tovább (gyengül), így a hibajel

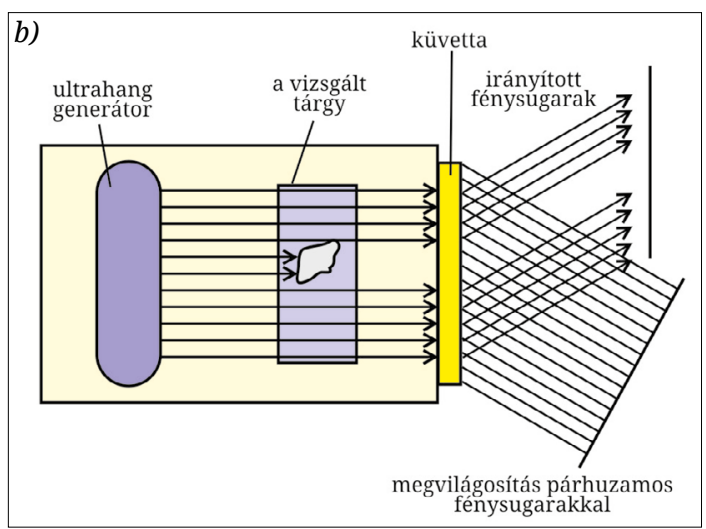

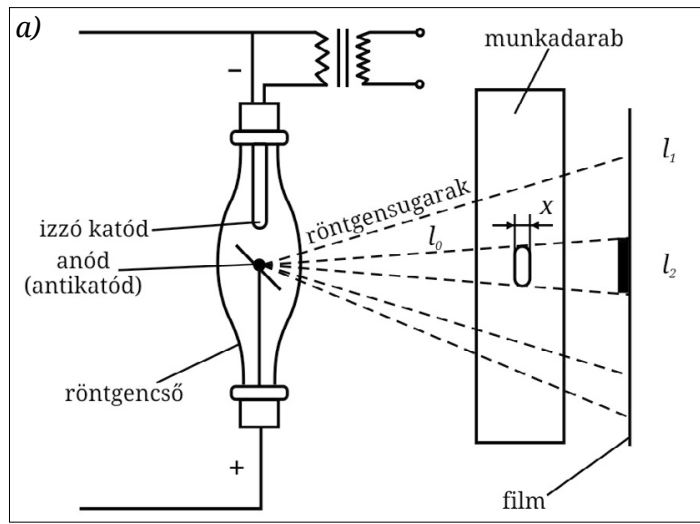

1. ábra. A röntgenvizsgálat és az ultrahangos hang-fénytani eljárás vázlata 
a végjel intenzitáscsökkenéseként jelentkezik. $\mathrm{Az}$ adóval szemben elhelyezett vevő érzékeli az átbocsátott ultrahangot, és a hibahelynél lecsökkent energiával arányos végjelet ad. A hibátlan, valamint a hibával rendelkező végjel különbsége adja a hibajelet (2a. ábra) [2]. Az eljárás lehetővé teszi a hibák alakjának, kiterjedésének megjelenítését, azonban nem mutatja ki a hiba mélységét, valamint a típusát.

\section{Impulzusvisszhang (Pulse Echo, PE) eljárás, merőleges vagy szögfejjel}

A hangnyalábot csatolóközeg segítségével vezetik a vizsgálandó tárgyba, ami a terjedés útjába kerülő „reflektorokról” visszaverődik. A visszaverődött mechanikai rezgés a vevőben elektromos jelet indukál, így az megjeleníthetővé válik analóg oszcilloszkóp katódsugárcsövén vagy digitális oszcilloszkóp kijelzőjén. A folytonossági hiány esetén a visszaérkező jel hamarabb jelentkezik, mint a hátfalról érkező jel, így a képernyőn megjelenő hibajel bemenő jeltől való távolsága arányos a hiba felülettől mért mélységével (2b. ábra) [2]. Ugyanis ha az anyagbeli $c$ hangsebesség ismert, akkor a rögzített $\Delta t$ időintervallumot használják az anyagban megtett $x$ távolság meghatározására:

$$
x=c \cdot \Delta t \text {. }
$$

A hibajel alakjából és nagyságából lehet következtetni a folytonossági hiány típusára és kiterjedésére is.

A folytonossági hiány típusának megítélése a hibáról érkező jel alapján esetenként nehéz feladat, ami szakképzett és gyakorlott vizsgálószemélyzetet igényel. Például tűszerű, a vizsgálófej mozgatásakor egy bizonyos helyzetben „felvilla- nó” jel érkezik egy gömbszerü gázzárványról, és fenyő alakú „lépcsős, tüskés” jel adódik egy több reflektáló felületelemmel rendelkező szilárd zárványról.

A folytonossági hiányok alakja közötti különbség jobban értékelhető két besugárzási irány alkalmazásával. A térfogatszerü gömbhiba visszaverő felülete iránytól függetlenül ugyanolyan jelet eredményez, azonban egy felületszerü hibánál a szögben érkező sugárzásnak ellenkező irányba verődése miatt lecsökken a sugár irányába eső komponense, ezáltal a jel magassága csökken.

Az ultrahangos vizsgálatok során előfordulhat, hogy olyan helyről is hibajelnek tűnő kép adódik, ahol nincs is folytonossági hiány. A hamis hibajel oka lehet:

- elektromos részek hibás elrendezése miatti interferencia;

-repedt adófej, ami a kibocsátott jelet zavarja;

- a csatolóközegben jelen lévő légbuborék;

- különböző élekről visszavert hullámok, azaz a vizsgált darab alakjától való függés;

- a szemcsehatárok;

- a hullámforma megváltozása;

- hegesztett kötéseknél a koronáról és a gyökről, valamint a hőhatásövezet határáról visszaverődött hullámok.

\section{Futásidő-diffrakciós (Time of Flight Diffraction, ToFD) eljárás}

A diffrakció a hang hullámhosszváltozása, amikor kölcsönhatásba lép egy anyag folytonossági hiányával. Ez a jelenség olyan szituációkban alkalmazható, amikor nem érhető el valódi viszszaverődés, de elegendő diffrakció lép fel a hang
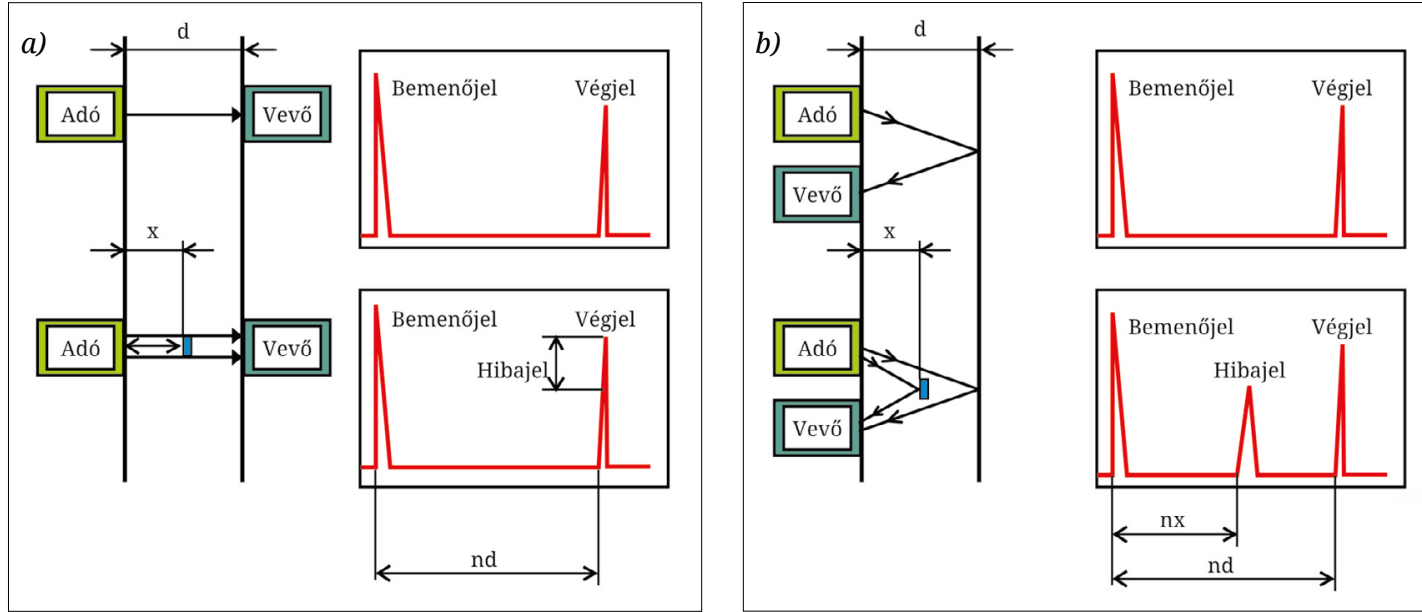

2. ábra. Átsugárzásos és impulzusvisszhang eljárás elve 
terjedési idejének megváltozására egy hangmagasságszinten. Ezt az eljárást használják annak a hibacsúcsnak a felismerésére, amely a szonda érintkező felületére merőlegesen helyezkedik el, továbbá a túlsó fal vizsgálatára, pl. a korrózió kimutatására is [3].

A futásidő-diffrakciós rendszerekben olyan szondát is használnak, amely a vizsgálati terület másik oldalán van. Az adószonda ultrahangimpulzust bocsát ki, amelyet az ellenkező oldalon a vevőszonda vesz. Sértetlen részben a vevőszonda által felvett jelek két hullámból származnak: az egyik a felület mentén halad (laterális hullám), míg a másik a távoli falról visszatükröződik (hátsó falvisszaverődés). Ha olyan folytonossági hiány mutatkozik, mint például repedés, akkor az ultrahanghullám diffrakciója következik be a repedés két (pl. alsó és felső) csúcsánál (3. ábra). Az impulzus mért terjedési idejének segítségével a repedéscsúcsok mélysége automatikusan kiszámításra kerül a trigonometria alkalmazásával.

A futásidő-diffrakciós eljárás nagy pontosságot kínál a repedéshez hasonló hibák kritikus falonkénti méretének méréséhez. Általában $\pm 1 \mathrm{~mm}$-nél nagyobb pontosság érhető el az anyagok széles vastagságtartományában, amelyekből pl. nyomás alatt álló szerkezeteket készítenek.

Előnyök:

-A folytonossági hiányok észlelésének nagy sebessége.

-A folytonossági hiányok pontos pozicionálása és mérése.

-A bizonyított reprodukálhatóság és pontosság $0,5 \mathrm{~mm}$.

-Folyamatos digitális felvételek grafikus képekkel.

- A detektálás független a megszakítások típusától és irányától.

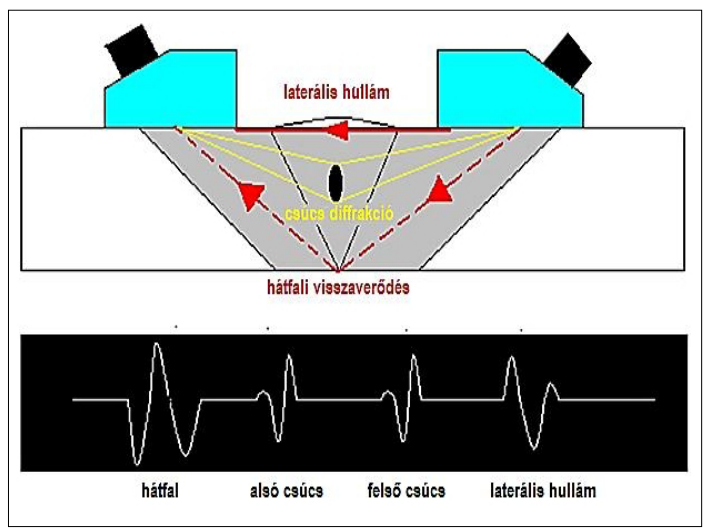

3. ábra. Futásidő-diffrakciós eljárás elve
- Konzisztens (egységes) eredmények a hőkezelés előtt és után.

-Konzisztens eredmények az előzetes és az üzem közbeni ellenőrzés során.

- Pontos eljárás a folytonossági hiány növekedésének mérésére.

- Nagyobb valószínűségű felismerést kínál.

-Az olyan sík folytonossági hiányok kimutathatók, amelyek nem merőlegesek a vizsgálati felületekre.

- Javul a kockázatcsökkentés.

- Működés közben nem kell evakuálni a környező területeket, mert káros sugárzást nem használ.

-A vizsgálati eredmények azonnal rendelkezésre állnak.

-A vizsgálatot $200^{\circ} \mathrm{C}$ felett is lehet végezni.

\section{Merítéses (Immersion) eljárás}

A kiterjedt vagy összetett geometriájú munkadarabok esetében problémát jelenthet, hogy az ultrahangos szondát a gyártmány felületéhez megfelelően csatolják. „Kényelmi” szempontból ezeket az alkatrészeket vízbe merítik, általában egy tartályban. A vízzel töltött tartályban elhelyezett vizsgálati objektum felületén az ultrahangszondát mozgatják, miközben a rezgés a vízből a vizsgált részbe jut. Miután a hang kölcsönhatásba lép a belső anyagszerkezettel, az esetleges hibákkal vagy a gyártmány túlsó felületével, a visszavert hanghullám visszatér a szondához (4. ábra). A visszhang érkezési ideje és amplitúdója lehetővé teszi, hogy azonosítsák, honnan és miről származik a jel.

Az ultrahangos szonda gyakran robotkarra van felszerelve, amelynek transzlációs és rotációs mozgásai vannak. A gyártmány pásztázási lefedettsége ezután automatizálható, előre beprogra-

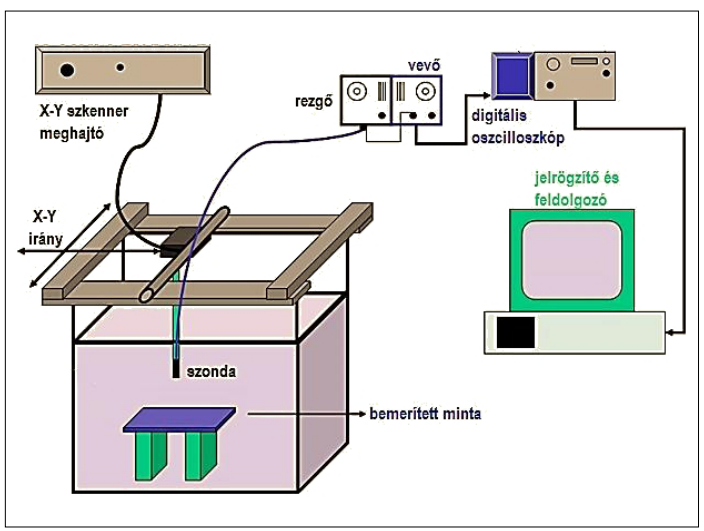

4. ábra. Meritéses eljárás vázlata 
mozott pályák használatával, amelyek több áthaladást is biztosítanak egy adott területen, vagyis az adatokat szkenneléssel gyüjtik, melyeknek képei megtekinthetők.

A víz csatolóközegként történő ilyen használata megszünteti a csatolás minőségének azon változásait, amelyek a hagyományos kontaktusos vizsgálat során előfordulhatnak. Ezen kívül lehetővé teszi a durvább felületek ellenőrzését is a csatolás elvesztése nélkül.

A merítéses ultrahangos vizsgálat rendkívül sokoldalú és jól konfigurálható egyszeres szondás, fázisvezérelt szondás és más fejlett technikák számára is. A nagyfrekvenciás érzékelőket általában szűkebb anyagvastagság-tartományban és könnyen átsugározható anyagokban, például ötvözetlen acélban használják, míg alacsonyabb frekvenciákra vastag profilokhoz és nagyobb csillapítású anyagokhoz, például rozsdamentes acélokhoz és műanyagokhoz van szükség.

Ezen vizsgálati eljárás alkalmazásával végzett tipikus ellenőrzési feladatok magukban foglalják az acéllemezek és -csövek korróziós viselkedésének feltérképezését, technológiai csövek hegesztésének ellenőrzését, az autóalkatrészek minőség-ellenőrzését és a kompozitkárok elemzését.

Előnyök:

- Nagy alkatrészek hatékony vizsgálata nagy felbontással, szemben a hagyományos ultrahangos eljárással.

- Nagy térbeli pontosságú szkennelés, amelyet lehetővé tesznek az automatikus szondamozgatás és az előre beállított adatgyűjtő programok.
-A vizsgált alkatrész alakjának, méretének és anyagának sokfélesége.

- Magas ismételhetőségi ráta a víz mint csatoló közeg állandósága miatt.

- A vizsgálat folyamatos nyilvántartása a hozzá kapcsolódó beolvasott képekkel.

Korlátok:

- Nem alkalmazható üzem közbeni ellenőrzésekre a szükséges merítő tartály miatt.

-Az alkatrészeket víz alá kell meríteni, melyek az anyagtípustól függően hajlamosak lehetnek korrózióra.

-A szonda hozzáférési korlátai gátolhatják a komplex geometriák ellenőrzését.

\section{Légcsatolásos (Air Coupled, AC) eljárás}

Egyes vizsgálatok és anyagok nem tolerálják a nedves csatolás alkalmazását, ezért bizonyos körülmények között levegővel csatolt, érintésmentes ultrahangos vizsgálat (5. ábra) is elvégezhető. Ez tehát a hang légrésen keresztüli alkalmazása, általában kisebb frekvenciák használatával [3].

Anyagtól és/vagy technológiától függően egyes anyagok megduzzadnak, hámlanak, korrodálódnak vagy más módon károsodnak. A légcsatolásos technológia lehetővé teszi olyan erősen csillapító anyagok vizsgálatát is, amelyek vízcsatolású ultrahangos vizsgálattal alig vagy egyáltalán nem tesztelhetők. Idetartoznak többek között a kompozitok, a méhsejtcellás anyagok, a habok, a kerámiák, a fák és a betonok.

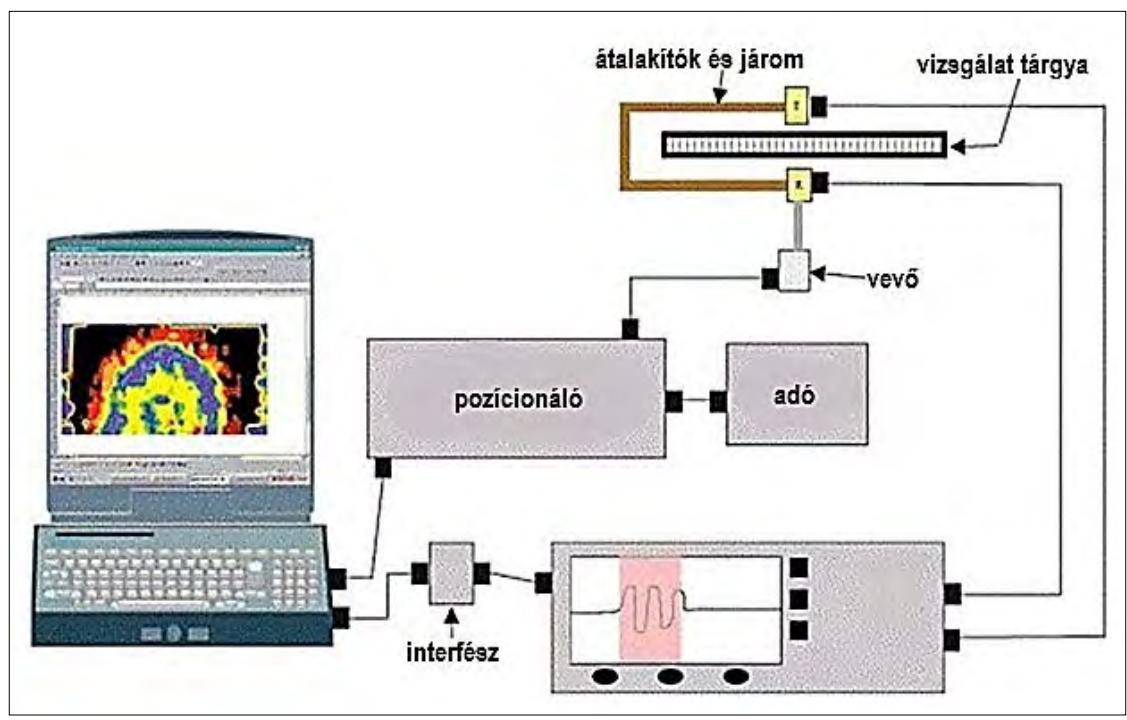

5. ábra. Légcsatolásos eljárás vázlata 


\section{Elektromágneses akusztikus átalakí- tós vizsgálat (Electromagnetic Acous- tic Transducer Testing, EMAT)}

Kontaktus nélküli vizsgálati eljárás, amely az elektromágneses hangelőállítást és -vételt használja az alkatrésszel való közvetlen érintkezés vagy nedves csatolás nélkül. Az elektromágneses akusztikus átalakítós vizsgálat különösen akkor használható, ha túlságosan meleg vagy hideg, tiszta vagy száraz a környezet. Mint a hagyományos ultrahangvizsgálat esetében, az elektromágneses akusztikus átalakítós vizsgálatnál is merőleges és szög alatti sugárzást használhatnak [4].

Az elektromágneses akusztikus átalakítós vizsgálat (6. ábra) egy olyan ultrahangos tesztelési technika, amely a jelet az ellenőrzött részben generálja. Az eljárás ultrahanghullámokat indukál a vizsgálati objektumban, két egymással kölcsönhatásban lévő mágneses mezővel. Az elektromos tekercs(ek) által generált, viszonylag magas frekvenciájú mező kölcsönhatásba lép az erős mágnes(ek) által előállított alacsony frekvenciájú vagy statikus mezővel, hogy Lorentz-erő jöjjön létre.

Ez a „zavar” átkerül az anyag kristályrácsához, rugalmas hullámot generálva. Inverz folyamatban a rugalmas hullámok kölcsönhatása mágneses mező jelenlétében áramot indukál a vevő tekercskörben. A ferromágneses anyagoknál a magnetostrikció további feszültségeket hoz létre, amelyek a jeleket sokkal magasabb szintre növelik, mint amit csak a Lorentz-erő képes elérni. Különféle hullámok generálhatók a nagyfrekvenciás tekercsek és a mágnesek különböző kombinációival.

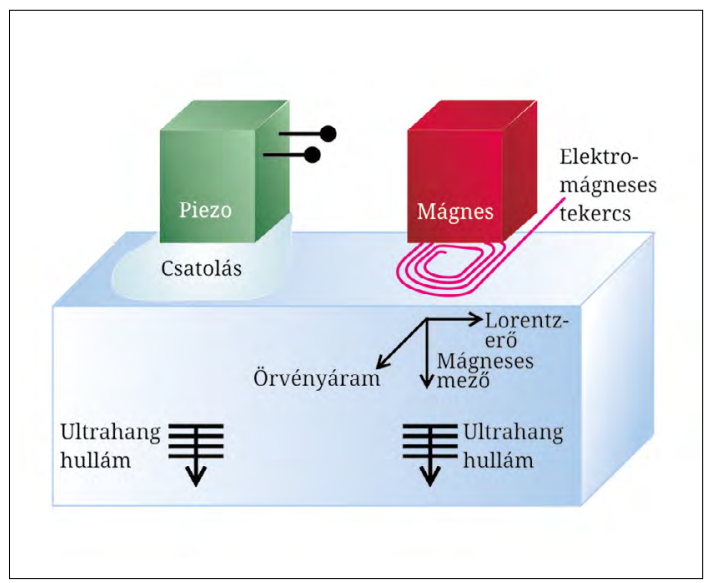

6. ábra. Hagyományos és elektromágneses akusztikus átalakítós vizsgálat elve
Mivel a hang az átalakító helyett a vizsgált részben keletkezik, az elektromágneses akusztikus átalakítós vizsgálat a következő előnyökkel bír a hagyományos piezoelektromos átalakítók alkalmazásával szemben:

-Száraz ellenőrzés, vagyis az eljárás nem igényel csatoló közeget a hang továbbításához, így igencsak alkalmas arra, hogy nagyon meleg és nagyon hideg alkatrészeket is vizsgáljon, automatizált környezetbe integrálva.

-Az eljárás bevonatokon keresztül is vizsgálhat, és szennyezőanyagok, oxidáció vagy érdesség nem befolyásolja.

- Az érzékelő könnyen telepíthető, és az elhelyezési szöge nem befolyásolja a terjedési irányt.

- Az egyetlen gyakorlati eszköz vízszintes polarizációval történő nyíróhullámok generálására, nagy mechanikai nyomás vagy kis sürüségü csatlakozók nélkül, amelyek akadályozhatnák az alkatrész letapogatását.

- Az eljárás tekercs antenna-típusú konstrukciója és egy többciklusos gerjesztés kombinációja nagyfokú specifikálást biztosít a frekvenciatartományban, ezáltal lehetővé téve a pontos hullámmód kiválasztását, ami nagy jelentőséggel bír az irányított hullámgenerálás és -értelmezés szempontjából.

Az automatizálás előnye az érzékelők integrálása a kereskedelemben kapható ipari robotokra, valamint a kollaboratív robotokra. Az adatok gyüjtésére és megjelenítésére szolgáló egyedi szoftver zavarmentes és intuitív felhasználói élményt nyújt, amelyet adaptálni lehet egyedi igényekhez is.

\section{Fázisvezérelt ultrahangos vizsgálat (Phased Array Ultrasonic Testing, PAUT)}

Ha a hozzáférhetőség korlátozott, akkor olyan hibakereső vizsgálati eljárásra van szükség, amely a teljes keresztmetszetben képes kimutatni megfelelő megbízhatósággal a hibákat. A fázisvezérelt ultrahangos vizsgálati eljárás a legalkalmasabb ilyenkor feladat elvégzésére. Lehetővé teszi az ultrahangsugárzási szögek változtatását, a dinamikus mélységi fokúszólást. A fázisvezérelt sugárzás rögzíthető digitális képet eredményez. A 7a. ábra a hagyományos és a fázisvezérelt ultrahangos vizsgálatot hasonlítja össze [5, 6].

A fázisvezérelt vizsgálati eljárásnál a vizsgálófej több rezgőből (piezoelektromos kristályból) áll, amelyek egymástól függetlenül is képesek működni. Ezekkel a rezgőkkel hoznak létre egy 
olyan hullámfrontot, amelynek belépési szöge (7b. ábra) változtatható:

$$
\Theta=\arcsin (C \cdot \Delta t / w) \text {, }
$$

ahol $C=$ az anyagbeli fázissebesség, $\Delta t=$ az egyes szondák pulzálásának fáziskésése, $w=$ a szonda középvonalának távolsága.

Mivel itt egy szélesebb tartományt vizsgálnak, nem szükséges pl. hegesztési varratok esetében a fejet pásztázva mozgatni, mint a hagyományos vizsgálatnál, hanem elég a varrat mellett párhuzamosan vezetni. Ennek nagy előnye, hogy az egyszerübb mozgatás segíti a vizsgálat rögzítését, amely a karbantartásnál, az állapotfelmérésnél és az állapotkövetésnél is rendkívül hasznos.

Mivel a vizsgálófej több rezgőből áll, és szektoriális vizsgálatnál egy szögtartománnyal vizsgálnak (pl.: $30 \ldots . .55^{\circ}$ ), a kimutathatóság valószínüsége növekszik, ezáltal jóval több információhoz lehet

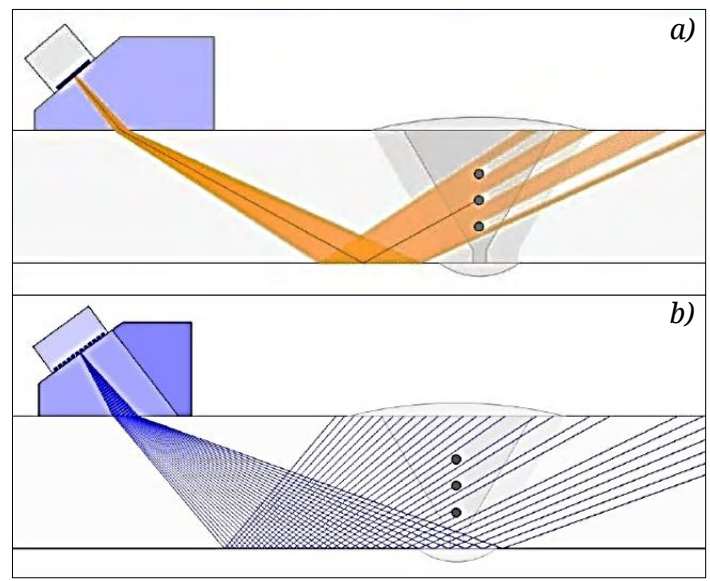

jutni, valamint az egymás alatt elhelyezkedő folytonossági hiányokat is ki lehet mutatni. A hibák pontos mérete és elhelyezkedése 3D-ben is megjeleníthető.

\section{Teljes mátrix rögzítés (Full Matrix Capture, FMC)}

Az FMC a PAUT technika továbbfejlesztése, és ugyanazokat a szondákat használja. Fő előnye, hogy nincs szükség a hangnyaláb fokuszálására vagy irányítására, mivel a teljes vizsgálati terület fókuszban van (8. ábra). Viszonylag toleráns az eltérő hibákkal és a szerkezeti zajjal szemben. Ez nagyon egyszerüvé teszi a beállításokat és a használatot. Hátránya, hogy a keletkező fájlméretek nagyon nagyok, és az adatgyüjtési sebesség lassabb lehet, mint a PAUT esetén [4].

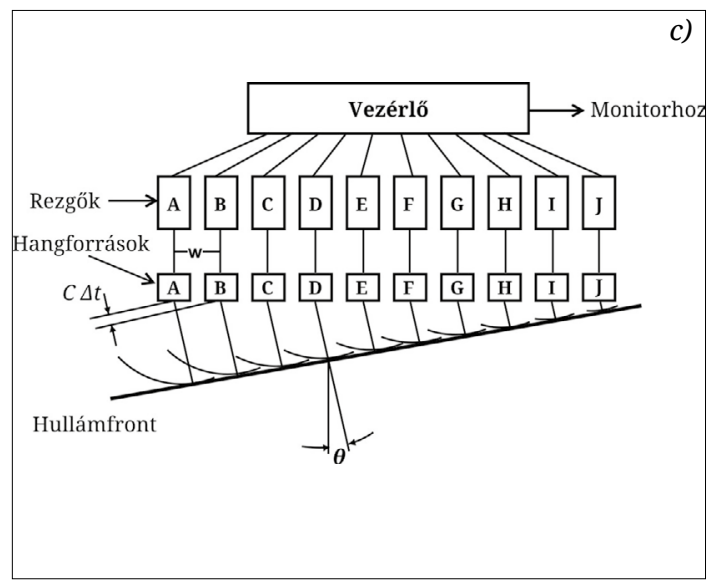

7. ábra. A hagyományos és a fázisvezérelt ultrahangos vizsgálat összehasonlítása
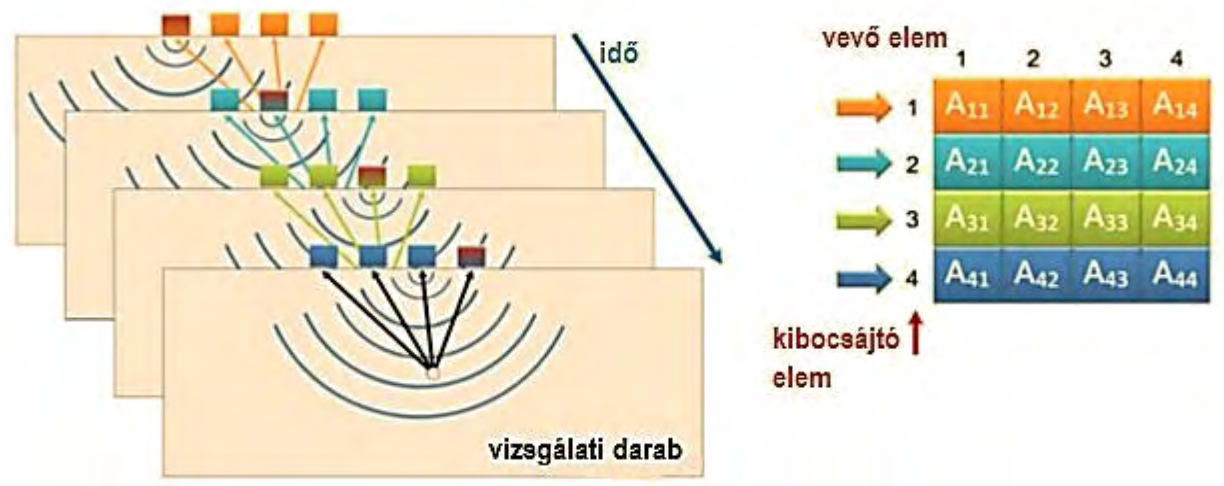
A teljes mátrix rögzítés (FMC) egy olyan adatgyüjtési stratégia, amely lehetővé teszi az öszszes lehetséges adás-vétel kombináció rögzítését. A begyüjtött adatokat valós időben dolgozzák fel az algoritmus optimalizált változatával, amely teljesen fókuszált képeket generál az FMC adatokból. Az új technika célja az ultrahangos ellenőrzés megbízhatóságának növelése, csökkentett költségekkel és jobb biztonsággal.

\section{Virtuális forrásnyílás (Virtual Source Aperture, VSA)}

A VSA egy olyan FMC-változat, amely megtartja a kiváló képminőség legtöbb előnyét, de jelentősen csökkentett fájlmérettel és kedvezőbb adatgyüjtési sebességgel, s így túlhaladhatja a PAUT-ot. A virtuális forrás pozicionálása - bizonyos távolságra a jelátalakítók mögött - lehetővé teszi, hogy több elem sugározzon, a késleltetési törvény szerint szimulálja az ultrahangos átvitelt. A 9. ábra szemlélteti, hogy az ultrahangos energiát közvetlenül a virtuális forrás bocsátja ki, gömbhullámokat generálva, fókuszálatlan, nagyon divergens sugár formájában [4].

\section{Rezonancia (Resonance) eljárás}

Rezonanciafeltétel akkor áll fenn, amikor az anyag vastagsága megegyezik a hang hullámhossza vagy annak többszöröse felével. Az ultrahang hullámhossz-szabályozását a frekvencia szabályozásával érik el. Ha van egy változtatható frekvenciájú adó, akkor azt úgy célszerü beállítani, hogy a vizsgált lemez vastagságának rezonanciafeltételét hozza létre. A rezonanciaállapotot könnyen felismerhetővé teszi a kapott impulzus amplitúdójának növekedése.

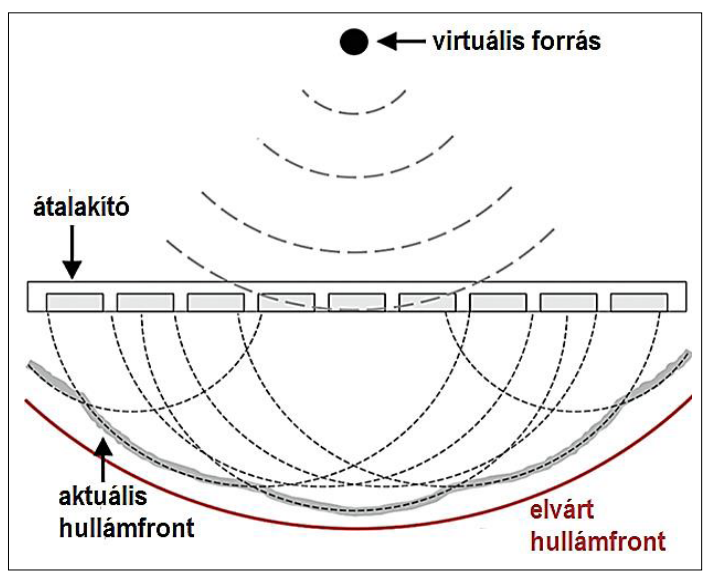

9. ábra. Virtuális forrásnyílás eljárás vázlata
A rezonancia elvére épülő eljárást vékony lemezek vastagságának meghatározására alkalmazzák. A $d$ vastagságú lemezt $c$ terjedési sebességű ultrahanggal rezonanciaállapotba hozzák. A rezonanciafrekvencia

$$
f_{\text {rez }}=c / 2 d \text {, }
$$

amelyből a vastagság meghatározható.

\section{Automatizált és részben automati- zált vizsgálatok}

Automatizált rendszereket ott alkalmaznak, ahol nagy mennyiségű hasonló alkatrészt kell vizsgálni. Ezek a rendszerek egy vagy több szondával működnek, amelyeket egy vezérlőegység illeszt a vizsgálati darabhoz, és egy előre meghatározott pásztázási séma szerint mozgatja azon. Az ultrahangos jeleket a kiértékelő egység dolgozza fel, és ha lehetséges, a monitoron jeleníti meg. Az összes mért adatot, valamint a szonda helyzetére vonatkozó információkat egy számítógépbe vezetik, ahol tovább feldolgozzák és kiértékelik. A számítógép vezérli a jelölő és válogató eszközt is, amely megjelöli a hibákat a vizsgált objektumokon. A számítógép további feladata a munkadarab mozgatásának ellenőrzése és a meghatározott vizsgálati körülmények jelzése. A 10. ábra egy tipikus automatizált ultrahangos vizsgálati rendszer blokkvázlatát mutatja [6].

\section{Következtetések}

Az ultrahangos vizsgálatot a gyakorlatban igen kiterjedten alkalmazzák a gyártást követő termékminősítő vizsgálatként vagy az üzemeltetés során az üzemeltetésből származó hibák felderítése céljából. Az ultrahangos vizsgálatok megbíz-

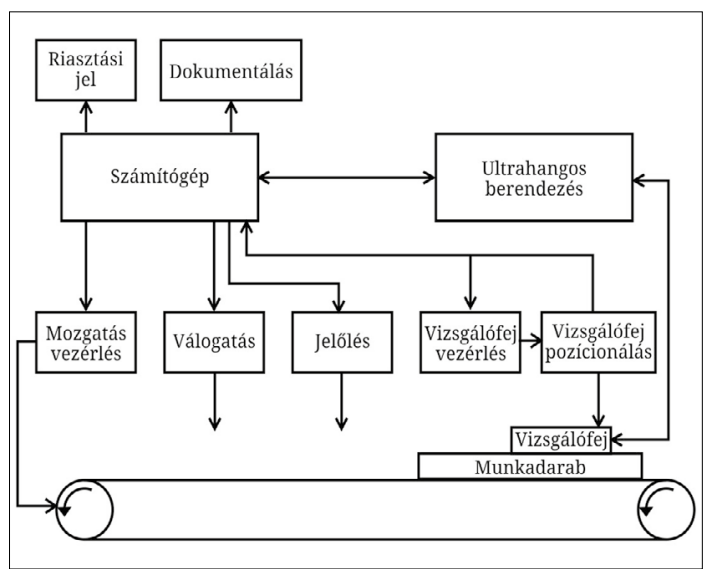

10. ábra. Automatizált ultrahangos vizsgálati rendszer vázlata 
hatósága a digitális technológia fejlődésével egyre növekszik. Ezen eljárások további előnye az adatok tárolásának, reprodukálhatóságának, adatok továbbításának terén tapasztalható.

\section{Szakirodalmi hivatkozások}

[1] Bagyinszki Gy., Bitay E.: Ultrahangos hegesztés alkalmazástechnikai jellemzői. In: Müszaki Tudományos Közlemények, 9. (2018) 31-34. https://doi.org/10.33894/mtk-2018.09.03

[2] Gál I.: Anyagvizsgálat előadásvázlat. Miskolci Egyetem, Mechanikai Technológiai Tanszék, 2007.

[3] What is Non-Destructive Testing (NDT)? Methods and Definition https://www.twi-global.com/technical-knowledge/faqs/what-is-non-destructive-testing\#MethodsofNonDestructiveTesting

[4] EMAT Technology.

https://www.innerspec.com/en-gb/knowledge/ emat-technology/

[5] Phased Array Services.

https://www.acuren.com/inspection/advancednde-ndt/phased-array/

[6] Training Guidelines in Non-Destructive Testing Techniques - Manual for Ultrasonic Testing at Level 2, International Atomic Energy Agency, Vienna, 2018. 